\title{
Моделирование с помощью молекулярной динамики низкотемпературной реконструкции поверхности (001) GaAs
}

\author{
Прасолов Н.Д. ${ }^{1,2}$, Гуткин А.А. ${ }^{1}$, Брунков П.Н. ${ }^{1,2}$
}

${ }^{1}$ Университет ИТМО, Россия, 197101, Санкт-Петербург, Кронверкский пр., 49

${ }^{2}$ ФТИ им. А.Ф. Иоффе, Россия, 194021, Санкт-Петербург, ул. Политехническая, 26

DOI 10.34077/Semicond2019-125

C развитием нанотехнологий значительное внимание уделяется исследованию изменения свойств поверхности кристаллических материалов методом наноиндентации, то есть вдавливанием твердого тонкого зонда (индентора) на глубину в несколько нм [1]. Обнаружено, что в этих полупроводниковых материалах, наноиндентирование вызывает формирование новых фазовых кристаллических состояний в деформированной области на глубине нескольких атомных слоёв от поверхности. Эти фазы в $\mathrm{Ge}$ [2] и $\mathrm{Si}$ [3] сохранялись и после отвода зонда от поверхности материала при не слишком высоких температурах, в то время как в GaAs формирование фазы было обратимым, несмотря на то, что моделирование производилось при температуре близкой к 0 К [4]. Влияние наноиндентирования на реконструкцию поверхности ранее не исследовалось.

Данная работа посвящена исследованию методами молекулярной динамики (МД) реконструкции атомных слоев на поверхности (001) GaAs в процессе наноиндентирования при температурах 1-15 К.

Установлено, что в области температур 1-15 К после выдержки при постоянной температуре в течение 200 пс до начала индентирования реконструкции поверхности GaAs не наблюдается и верхний слой состоит из атомов As, образующих квадратную решетку $(1 \times 1)$ (см. Рис. 1, вне области индентирования). При погружении индентора на некоторую глубину на поверхности GaAs в области индентирования атомы As начинают образовывать димеры (Рис. 1, 2), количество и длина цепочек которых увеличиваются с глубиной

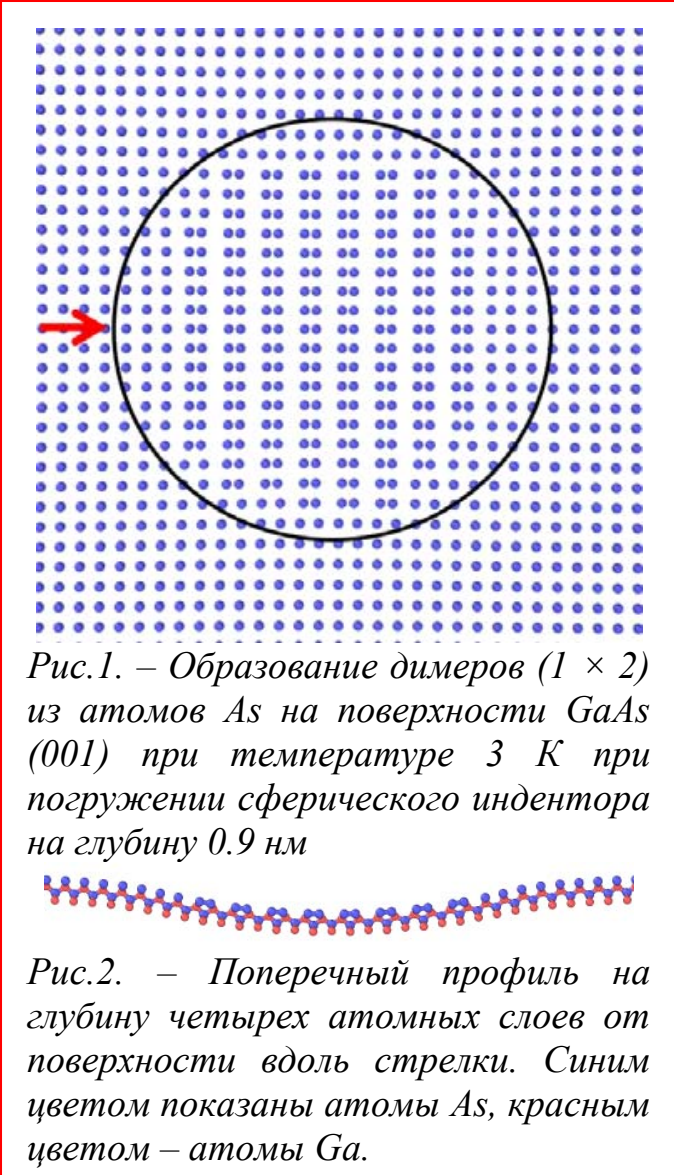
индентирования, что приводит к образованию области реконструкции поверхности, в которой наблюдается $(1 \times 2)$ структура.

Расчеты методом МД, проведенные без воздействия индентора, при температурах 32-45 K показали термически активированное образование димеров атомов As на исследуемой поверхности. Энергия активации формирования поверхностного димера As заметно ниже 0.1 эВ, в то время как для его диссоциации требуется затратить энергию около 2 эВ. Последнее и объясняет стабильность реконструкции поверхности GaAs (001) с образованием димеров атомов As при повышенных температурах.

[1] A.C. Fischer-Cripp, Nanoindentation, Springer-Verlag, N.Y. (2011).

[2] P.Z. Zhu, Z. Fang. Applied Physics A, 108, 415 (2012).

[3] C.F. Sanz-Navarro, S.D. Kenny, R. Smith, Nanotechnology, 15, 692 (2004).

[4] D. Chrobak, K. Nordlund, R. Nowak, Phys. Rev. Lett., 98, 045502 (2007). 